February - 2009

\title{
Recurring Issues Encountered by Distance Educators in Developing and Emerging Nations
}

\author{
Clayton R. Wright \\ Canada
}

\author{
Gajaraj Dhanarajan \\ Wawasan Open University, Malaysia \\ Sunday A. Reju \\ National Open University of Nigeria
}

\begin{abstract}
This article explores a number of challenges faced by e-learning or distance educators in developing and emerging countries, provides a context for many of the challenges, and outlines some measures devised to overcome them. These educators must determine a sound rationale for employing online learning, recognize that technology is only part of the educational transformation process, address the lack of infrastructure and the cost of Internet bandwidth and equipment, counter the cultural imperialism of courseware from Western nations, deal with limited educational resources, place a greater emphasis on quality assurance systems and change negative perceptions of distance education, respond to the needs and concerns of both students and faculty, access or develop up-to-date educational resources, and consider the implementation of mobile learning. The continued growth and success of distance education in developing and emerging nations will depend on the extent to which issues covered in this article are addressed as they bear on the quality of the learning experience provided to students.
\end{abstract}

Keywords: distance education; online learning; e-learning; technology; developing countries; emerging countries

\section{Introduction}

Education can be the difference between a life of grinding poverty and the potential for a full and secure one; between a child dying from preventable disease, and families raised in healthy environments; between orphans growing up in isolation, and the community 
having the means to protect them; between countries ripped apart by poverty and conflict, and access to secure and sustainable development. (Mandela \& Machel, 2002, p. A15)

Leaders in developing and emerging nations promote education as a means to improve their peoples and countries. "There are many reasons for the growth [of distance education] but none is as compelling as the hunger for learning felt by those who have been denied it for generations" (Dhanarajan, 2001, p.61). A number of recurring issues seem to emerge when developing countries attempt to implement a technological form of distance education or its many variations - e-learning, distributed learning, or online learning. This article provides an overview of key issues faced by distance educators in developing countries, describes some of their successful practices, and outlines additional measures that these educators could consider or are implementing. Note that many of these issues are not new (Muilenburg \& Berge, 2001; L.Bunn, 2001; Leggett \& Persichitte, 1998); they tend to re-emerge with every significant development or paradigm shift in the educational system. Also note that developing and emerging nations are not homogeneous. Just as each country displays different attributes pertaining to population, culture, language, social structures, politics, economical development, resources, the use of technology, and so forth, the issues described below do not apply equally to every developing or emerging nation.

\section{The Issues}

\section{Developing a Sound Rationale and Vision for the Distance Education Initiative}

Government and institutional personnel in developing countries often decide to employ e-learning or online learning without fully realizing what it means for their students and their institutions. If students are still reading by candles and kerosene lamps, expecting them to learn online may not be realistic. Online learning is attractive to institutions that want to be perceived as being progressive; however, establishing online programs may not be the wisest use of scarce resources. It may be better to use the limited funds to encourage greater school attendance, ensure students are well fed, and/or hire more tutors. Effective teachers, whether they meet students face-to-face or via a videoconferencing system or prepare online course material, are still the key ingredient in any educational system. According to Wagner et al. (2005) “...the past decade provides strong evidence that misguided policies and funding for internet communication technology (ICT) in education may fail to have the desired education outcomes, while costing more than other education interventions" (p. 12). Technology may not be the appropriate or only solution to an educational problem (Wells \& Wells, 2007).

Some institutions and government departments are attracted to online learning because they think it will save them a significant amount of money and human resources. They frequently imply that distance education and technology are panaceas for all that ails their educational system. Cost 
savings can occur if a large number of students are involved (Trindade, Carmo, \& Bidarra, 2000) and/or if fewer educational facilities are built, but instructors, tutors, course production teams, technical support personnel, and other human resources are still required, and they make up a substantial portion of the educational budget. According to G. Pruitt, president of Thomas Edison College, "One of the biggest myths about online education is that it's cheap. To produce highquality distance education courses, it's very expensive" (Silberstein, 2007). Distance learning should be about access, equity, and the distribution of quality products to a wide audience; cost savings are just one of the potential benefits.

There are numerous legitimate reasons why governments and institutions should introduce technologies into distance education, such as "greater information access; greater communication via electronic facilities; [the introduction of] synchronous and asynchronous learning; increased cooperation and collaboration; cost-effectiveness [e.g., by reaching different students and in greater numbers]; and pedagogical improvement through simulations, virtual experiences and graphic representations" (Sife, Lwoga \& Sanga, 2007), as well as the opportunity to offer those who are working full-time or have household commitments "a second chance ...to improve their skills and further their education, regardless of age, gender, ethnicity or social background" $(\mathrm{Ng}$, 2007). Distance education may also be used to bridge the digital divide, to reduce the "brain drain" of individuals who leave to study abroad, to broaden access to individuals who have had limited opportunity, and to spur social and economic development. Many distance education initiatives have been established to assist those who are poor and those who live in rural areas. However, despite the growth in information and communication technologies, inequalities between rich and poor, urban and rural, and male and female continue to exist (Gulati, 2008).

Educators in developing countries have employed distance education successfully to provide accreditation to teaching and health professionals, to inform youth of various lifestyles or career paths, to help farmers improve agricultural production, and to increase literacy. More recently, distance education has been used to facilitate an interest in local governance and to introduce egovernance. For many students, distance education provides a path to a better life: the more educated they are, the better jobs they will obtain, and the better they will be able to meet the needs of their families.

\section{Recognizing that Technology is only One Component of the Educational Transformation}

While shiny new technology appeals to politicians and educators alike, it should not be adopted uncritically or without careful planning. Wright (2007b) identifies necessary conditions for the effective use of technology in a distance education setting:

1. Decision-makers must identify the problem the technology will address or the benefits the technology will bring to education and/or administrative processes.

2. Educational and governmental bodies must be committed to the goals toward which the technology will be applied, ensure that issues regarding accessibility and equity are addressed, 
develop measurable objectives and realistic timelines, assign specific responsibilities to individuals and groups who will facilitate the change process, and provide the necessary resources.

3. Key individuals, in collaboration with other stakeholders, must develop a plan to guide the implementation.

4. The selected technology must be effective for its intended use and meet the needs of potential users.

5. The curriculum should be adjusted to make the best use of existing and possible future technological developments; the technology should promote meaningful interaction between the learner and the learning material, instructors, tutors, other learners, and the community.

6. Instructors must receive hands-on training in the use of the technology and its potential benefits to learning and instruction. They must learn to provide effective student support and to conduct simple troubleshooting.

7. Incentives should be provided to encourage instructors to get involved with this new method of delivery. The time and effort required to develop and support online courses must be recognized.

8. Copyright policies should be adjusted, if necessary, to enable the conversion of existing materials into electronic media.

9. The technology must be maintained, supported, and secured.

10. Organizational policies and management structures must be adjusted to cope with flexible delivery methods, provide prior learning assessment, support independent study students, address issues such as security, plagiarism, and ethical online behaviour, and assist students who lack access to and/or experience with the technology.

11. Consideration must be given to how the technology and software will be updated in the future.

12. Procedures for continuous assessment should be established.

13. Educational administrators must be willing to review technological implementation plans regularly and revise them as necessary.

Planning is an imperfect art as there will be unforeseen developments and challenges. "Nevertheless, the imperfect nature of planning and management does not diminish the need for deliberate strategies to implement effective technology-based teaching" (Bates, 2000, p. 212). The extent to which an institution adjusts its practices and processes greatly affects the success of 
technological implementations. In one institution in Southeast Asia, computers were installed up to two years after staff requested them; by then, the equipment was outdated, new software was required, and those who asked for the equipment had moved on to other positions. As computer performance seems to double every 21 months (Strong, 2007) and new software is developed to take advantage of this increased performance, equipment specifications and implementation plans must be revised on a regular basis.

When distance education is being implemented, especially when it has a technological component, there is a need for leaders who are flexible, open to new ideas, and willing to make decisions. In many developing countries the decision-making process is flawed due to the involvement of decision-makers who have limited or no experience with technology, distance education, and change management. Those who will be making significant decisions about technology should use it on a daily basis. They should have some experience with specific equipment or programs they are selecting; be aware of the potential impact of the technology upon learning, instruction, and administrative systems; and keep abreast of emerging trends.

Institutions must put in place a clear, detailed plan for implementing technology in distance education. They must involve all stakeholders so there is a common vision and shared ownership for the plan (Levy, 2003). Implementation plans are likely to fail if they do not involve stakeholders such as the department or ministry of telecommunications, or if they imply that teachers will lose their jobs when courses are placed online. The plan must be updated continually to accommodate new information and communication technologies, and a strong yet flexible leader must convincingly communicate the plan to all constituents. Purchasing hardware is just one of the many steps involved in implementing technology successfully in a distance education setting.

Despite the emphasis on the use of educational technology in this article, it must be recognized that developing countries continue to have success with paper-based and broadcast media forms of distance education as these are reliable and sustainable (Leary \& Berge, 2006).

\section{Addressing the Lack of Infrastructure and the Cost of Bandwidth}

The lack of a sustainable and accessible electrical and telecommunications infrastructure inhibits not only economic growth (Wallsten, 2005; Fay \& Morrison, 2007), but also growth in the educational sector. In June 2007, Kenya's education minister, Professor George Saitoti, stated that approximately $80 \%$ of the primary schools and $35 \%$ of secondary schools were not connected to the power grid (Ngare, 2007). Introducing e-learning to these schools will be a challenge. Alternative power sources such as solar and wind must be considered as well as equipment that uses minimal power or includes electrical generating devices. In Namibia, solar panels and wind turbines are being used to generate electricity to support Internet services, computers, and servers in rural areas. This type of infrastructure has, in part, enabled SchoolNet Namibia (see http://www.schoolnet.na/) to provide computers, training, and support to more than 300 schools via a significantly discounted flat-rate wireless Internet network. Affordable and reliable electric power would greatly facilitate the adoption of online learning. 
In eastern and southern Africa, the cost of Internet access can be 20 to 40 times the cost in North America, as 80 per cent of the Internet traffic is routed through satellites (Wadvalla, 2008; World Bank, 2007a). Satellites over Africa and the South Pacific provide slower transmission rates than optical cable primarily due to signal delays and narrow bandwidths. Further, many of the satellites supplying signals to Africa and the South Pacific were launched more than 20 years ago and are aging. A marine and terrestrial infrastructure backbone, recently approved by the World Bank to serve eastern Africa, would substantially reduce costs (World Bank, 2007a). In addition, 03b Networks, Google, Liberty Global, and the HSBC Bank plan to launch a high-speed, lowcost network of 16 satellites which "will enable the spread of locally generated content and elearning, [thereby] encouraging social and economic growth in the developing world" (BBC News, 2008). Once a robust link to countries beyond Africa is established, it would be helpful if a network of telecommunication or Internet hubs were implemented in Africa. Seventy-five percent of e-mail and telephone messages between African countries are routed through Britain or the United States (Nixon, 2007), thus, it can be expensive to communicate and use services such as Web 2.0 tools (e.g., wikis, podcasting, and multimedia sharing services) that may require large bandwidth. A fixed basic Internet line in Rwanda costs US\$90 per month and wireless Internet service is US\$63 per month. The average Rwandan makes US\$220 a year (Nixon, 2007). The high cost of Internet access partially explains why Africans comprised only $1.6 \%$ of the world's Internet users in 2005 (Zeleza, 2005) and 3.6\% in 2008 (Association for Progressive Communications, 2008). Only 6\% of the Latin American population had access to the Internet in 2006 (Mahan, 2007).

Even if the infrastructure is somehow present, the operating cost has ensured that [the] internet remains out of reach from the bottom of the pyramid. Poor speed, erratic connection-drops, and pathetic electricity supply has buttressed the cause for no use of the internet even in the areas which are advanced in relative terms. (Narayan, 2007, p. 3)

The cost of bandwidth is relatively expensive for most people living in developing countries, but at least they potentially have access to it. This is definitely progress, because in 1996 only five countries in Africa were connected to the Internet and now all are connected (Zeleza, 2005).

Once the telecommunications backbone is established, wireless systems could be added to deliver services locally and to serve rural areas in which many marginalized and under-served people live. The developing countries have the advantage of learning from the experiences of other countries and are able to leapfrog over various stages of development. For example, instead of implementing hardwired terrestrial systems, developing countries can employ wireless technology. An accessible and reasonably priced electrical and telecommunications infrastructure is essential if e-learning is to spread beyond large urban areas. 
According to Gross (2006), "The challenge [in Africa] from a governmental and regulatory perspective is what can and should be done to create an environment to encourage investment, both domestic and foreign, by the private sector" in the telecommunications industry. Perhaps governments should ensure that no one company has a monopoly for this service and that a healthy competition among wireless providers is nurtured. Governments need to remove regulatory barriers that prevent the establishment of a healthy competitive environment and encourage investment (Thornton, 2008) or take a more socialist view and ensure that all citizens have access to the Internet at a price they can afford. Countries such as Tanzania have eliminated taxes on computer equipment and reduced license fees payable by telecommunication companies. Liberia intends to follow Tanzania's policies by "waiving custom duties on imported ICT-related equipment so as to enable Liberians to have more access to them" (Balancing Act New Update, 2008). By connecting learning centres to the Internet, Sri Lankan officials can introduce the web to local communities. Once the Internet connection to learning centres has been made, private contractors can take the Internet connection from the learning centres into the local communities. These contractors may establish Internet cafes which are flourishing in developing countries such as Peru where "more than 80 percent of internet users connect from collective places" such as cyber cafes (Fernández-Maldonado, 2004). The money generated by the private contractors can be used to partially cover the cost of delivering the Internet to the learning centres. By providing an Internet connection to a learning centre and enabling local contractors to link to the connection, the contractors are able to provide a service that might have been unaffordable if they had to bear the entire cost of bringing the Internet to the community. This type of governmentprivate partnership is beneficial to all.

Bandwidth is not the only issue in the development of network infrastructure: ease of installation, susceptibility to interference, coverage, data security, and costs also are relevant. Maseno University in Kenya considered using copper wire, optical fibre, wireless networks, and/or satellite signals to provide the connectivity it required. The National Open University of Nigeria decided to use Nigeria"s Communications Satellite (NIGCOMSAT) to link its main campus with its video conference facilities located in study centres across the country. Each institution had to carefully assess its infrastructure and learning needs then determine a solution that took into account environmental constraints.

The infrastructure challenges in Africa are similar but not identical to those in Latin America and the Caribbean, where the infrastructure has slowly improved in quality, reliability, and coverage. However, governments must still make regulations that foster infrastructure development, increase their infrastructure spending, and spend funds wisely on initiatives that will broaden access (Fay \& Morrison, 2007). Regardless of the type of infrastructure that is implemented, it must be designed to accommodate the goals of the distance education program (Bates, 2000).

\section{Obtaining Equipment When Funds are Limited}

When compared to the average wage, the cost of equipment can be expensive in many developing and emerging nations. Consider that 650 million of India's 1.1 billion people still earn two dollars a day or less (World Bank, 2007b) despite India's emerging status as an economic powerhouse. 
Personal ownership of a computer is a dream for many; telecentre operators (see http://www.telecentre.org/) provide services to local communities as they attempt to bridge the digital divide.

There are a number of low-cost computers that educators in developing countries can consider. These options are significantly less expensive than a used Pentium III computer, which can cost up to US\$800 in Brazaville in the Democratic Republic of Congo (Chibomba, 2007). Computers available through the One Laptop per Child Project (OLPC, see http://laptop.org/), which are currently sold at US\$180, seem to be built with constructivism and connectivism in mind. They are capable of mesh networking and the software seems to accommodate collaborative activities easily. These computers appear to be well suited for elementary school-aged students in areas where electrical and Internet infrastructure may be non-existent as they consume $10 \%$ to $20 \%$ of the wattage of normal laptops; can generate their own power by use of pull chords, solar panels, and hand cranks; are water- and dust-proof; and have very few moving parts. While the Intel Classmate PC (see http://www.classmatepc.com/), priced at US\$230 to US\$250, may be best for a secondary school market, the OLPC laptop and Intel Classmate PC are not the only low-cost personal computers. A Canadian company, InkMedia (see http://www.ink-media.com/) has produced a US\$300 Linux-based laptop for the developing world. Lenovo, which bought the IBM Thinkpad license in 2005, offers a US $\$ 199$ computer to the 800 million people who live in rural China (McDonald, 2007). That sounds like a good deal until you realize that the average wage in rural China in 2006 was US\$560, although it is increasing at a rate of $10 \%$ each year. Currently, there are over 50 initiatives that involve the use of low-cost computers to serve students in developing countries (see http://www.infodev.org/en/Publication.107.html). Despite recent downsizing of the management of the OLPC initiative, OLPC is credited with shining a light on the technology needs of these students and for inspiring others to develop low-cost computers.

Rather than purchase new computers, some countries such as Kenya, Namibia, Trinidad and Tobago, and Uganda have the option of obtaining refurbished computers from non-governmental agencies. Computers for Schools Kenya (see http://www.cfsk.org/) has provided computers to 300,000 students in marginalized communities (Okono, 2007). This organization receives donated computers from Canada, Great Britain, the Netherlands, Norway, and the United States, then repairs them, removes residual data installed by previous owners, loads appropriate software, and tests the equipment. This work is primarily completed by student interns and volunteers who acquire ICT skills that enable them to obtain gainful employment. However, a number of challenges are related to refurbishing computers, including dealing with the compatibility problems associated with the wide variety of computers received, the potentially high maintenance costs, and restrictions on software because old machines may not be able to run new programs (Ministry of Education, Science, and Technology, Government of Kenya, 2005).

Educational institutions and governments must assess the true cost of the technology, not just its initial purchase cost which may be only $20 \%$ to $25 \%$ of the actual cost of ownership (Wheeler, 2004). Maintenance, software, and training costs must also be considered. Whatever the cost of information and communication technologies (ICTs), they are competing against food and health services for the limited funds of developing and emerging nations. 


\section{Countering Cultural Imperialism and Addressing Cultural Diversity}

Western courses bring Western values (Edmundson, 2007). Many in developing countries, particularly Africa, feel that they are forced to accept courses from Western societies when, in fact, they have a choice. They prefer to use materials developed locally.

There are at least 6,912 living languages in the world, of which about 347 have more than one million speakers (Gordon, 2005). In Africa, where several countries have more than 20 languages or dialects, it may not be feasible to develop print materials and courseware in a variety of languages. If the courseware is produced in one language, which should it be? Often, the language selected is one from colonial times thus complaints of cultural imperialism are heard. Further, a variety of cultural groups have an oral tradition that is best supported by lectures and group discussions. Other cultural groups are uncomfortable with the concept of critical thinking espoused by many distance educators, as they feel it will lead to criticism of their elders. For example, in an article describing the development of distributed learning in Bhutan and Nepal, Rennie \& Mason (2007) state, “...the concept of 'critical thinking' so highly regarded by Western academics, is anathema to the traditional Buddhist educational system, and this actively works against the idea of student-centred learning that values curiosity, rationality, and creative approaches to learning" (p. 3). A telemedicine project in Thailand failed not only because of the high satellite communication costs, but also because medical personnel in urban areas were reluctant to consult with those in rural areas. The technology was not able to bridge social barriers. The implementation of technology does not mean that cultural and social differences disappear; sometimes, the differences are magnified. Overcoming cultural and religious perceptions relative to technology and its use can be more difficult than actually implementing technology.

In an effort to maintain an indigenous culture and to reach those who live in rural areas or on the street, presenting courses in local languages makes sense. However, if equipment manuals for vocational courses are available only in a foreign language, or if business is conducted in a language such as Mandarin and English, it might be beneficial to expose students to these languages. If the need to have resources in a local language is paramount, groups of ten or more educators could establish a language-specific version of the Wikiversity (see http://www.wikiversity.org/), which was founded by the Wikimedia Foundation to create and host free learning materials and activities. Also they could consider using Jottit (see http://jottit.com/), which is a wiki that is easy to set up and does not require students to have an e-mail account in order to access the information.

\section{Dealing with Limited Resources}

Educators in developing countries are aware that external funding from international development agencies and corporations may not always be available; projects may not be sustained once the external funding has ended. Thus, educators need to collaborate across borders, especially regarding the development and delivery of courses (Nafukho, 2007) and should consider the use 
of open-source course management and delivery software (Wright, 2006), such as Moodle (see http://moodle.org/) and Sakai (see http://sakaiproject.org/) . "Open source software offers the potential to reduce the cost of the software while providing an institution greater control over its destiny" (Coppola, 2004).

Educators can easily minimize the duplication of effort required to develop materials. The Commonwealth of Learning (COL), for example, worked with the eight countries of the Southern African Development Community (SADC, see http://www.sadc.int/) to develop training materials to enable teachers to enhance their professional skills through distance and open learning. Teams of writers from Botswana, Namibia, South Africa, Zambia, and Zimbabwe developed the modules. Throughout the writing phase, content input and review of the materials remained the collective responsibility of all participating countries. Once the core modules were developed, each country was able to adapt them to meet the needs of its people. The COL has also initiated the Virtual University for Small States of the Commonwealth (VUSSC, see http://www.col.org/colweb/site/pid/100), which is a collaborative initiative to develop and share courseware (Butcher \& West, 2007), and the WikiEducator (see http://wikieducator.org/), which is a collaborative initiative to develop and make available a free education curriculum by 2015 .

With collaboration, the cost of a particular initiative to any one institution, agency, or country is minimized and the quality of the finished product can be higher than if only one institution or country undertook the development of the learning materials.

Developing and emerging nations could establish regional learning repositories that contain learning objects or digitized learning activities that meet their specific needs as well as complement the contents of existing open-source learning repositories such as the Multimedia Educational Resource for Learning and Online Teaching (MERLOT, see http://www.merlot.org/). If educators develop their own learning objects or online activities, they should ensure these are more than just electronic page-turners. According to Wright (2007a), the online learning activities should achieve the following:

- engage and motivate the learner by including online games, role-plays, and simulations;

- demand that learners interact with the online material, with their peers, and their community by using the various socialization tools that are available on the web;

- encourage critical thinking, creativity, and problem-solving;

- $\quad$ provide opportunities for online practice and knowledge transfer;

- $\quad$ offer timely, constructive, relevant, and frequent feedback; and

- provide links to resources beyond the content and the learners' communities. 
If regional learning repositories are to be successful, educators must be willing to contribute some of their own funds and energy. They cannot rely solely on external funding from organizations such as the William and Flora Hewlett Foundation (see http://www.hewlett.org) that support open educational resource initiatives designed to equalize access to knowledge and educational opportunities. The Teacher Education in Sub-Saharan Africa (TESSA, see http://www.tessafrica.net/) initiative is an example of a successful collaborative effort that develops open educational resources and provides guidance to teachers. This initiative involves 18 international organizations and educational institutions. African Virtual Open Initiatives and Resources (AVOIR, see http://avoir.uwc.ac.za/), which comprises 13 African universities, focuses on developing free software that is relevant to African users.

Collaborating on course delivery and student support may be more difficult than collaborating on course development. However, the Association of African Distance Learning Centres (AADLC, see http://www.aadlc.com/), part of the Global Development Learning Network (GDLN, see http://www.gdln.org/), has enabled individuals and teams to share knowledge and learn how best to offer distance education. One of its priorities is the provision of effective, cost-efficient support to distance learners. The partnership of 15 ADLC learning centres connects governmental, nongovernmental and development agencies, and private-sector individuals across countries via interactive videoconferencing and the Internet. Distance educators in developing countries also need to explore the establishment of a cadre of tutors who could serve more than one institution. Companies in India and in many developed countries provide 24/7 online tutoring and student support services. If there is a lack of specific content expertise or the number of students does not justify hiring full-time faculty at one institution, then institutions could consider collaborating on the provision of tutoring services. Collaborative efforts can address the challenge of limited resources and can be beneficial to all involved.

Working across borders can address the lack of educational resources and the need to introduce faculty to new instructional methods. Recently, the United Nations established UNeLearn to collaborate on the deployment of e-learning in over 160 developing countries. In addition, the U.S. Agency for International Development stated that it plans to establish a virtual network that will enable institutions in Africa to collaborate with their American counterparts (Lindow, 2008). Thus, the institutions will be able to partner on projects in education, economic development, food security, and health. According to Silas Lwakabamba, rector of the National University of Rwanda, the partnership will benefit African universities by "building the capacities of their graduate programs, introducing interactive teaching methods, providing training and mentorship opportunities for senior faculty members, and bringing more women into academic ranks" (Lindow, 2008). 


\section{Placing Greater Emphasis on Quality Assurance}

Frequently, face-to-face instruction is associated with quality teaching even if the instructors are poorly trained or lack suitable credentials. Conversely, distance education has been viewed as second-rate education that focuses on memorization rather than on problem-solving and is seen as a costly enterprise, especially when information and communication technologies are introduced. Perraton (2007) expresses one view of distance education in the developing world:

Open and distance learning is regarded, by students and ministries of education alike, as a second-rate system, used to offer a shadow of education while withholding its substance. It is an inefficient but cheap way of containing educational demand without meeting it. ( $\mathrm{p}$. 207)

This view of distance education is widespread not only in Southeast Asia and Africa, but also to a lesser degree in developed countries "... as this was a common attitude in the West until about twenty years ago (and some may say is still prevalent in subject-specific areas)" (Rennie \& Mason, 2007, p. 3).

According to Professor Dhanarajan, vice-chancellor of Wawasan Open University,

The mode of delivery, whether face-to-face or virtual, actually has little to do with the quality of education. What ${ }^{\text {es }}$ more important are things like, is there a careful measurement of learning outcomes and is the university benchmarking its development? ... [and] whether the curriculum is relevant to the environment. ( $\mathrm{Ng}, 2007)$ High-quality educational materials tend to be produced by people who have a positive attitude towards change and care about what they do and how they do it. (Wright, 2008b)

Those who are likely to make key decisions about technology and distance education and those who are highly regarded as people of influence are generally in their fifties or sixties. These individuals may subtly resist technological solutions because technology was not part of their educational experience (Omofaye, 2006). Technology is not the issue, but rather how it is used and the attitudes people have about it. Educators should not only be exposed to the literature about effective distance programs, but must also see them in operation and speak to students whose lives have changed because they were able to access distance education courses. Increased awareness should improve attitudes towards the implementation of technologically-enhanced distance education. 
One of the reasons why distance education is not respected in some countries is the lack of quality assurance systems that continually measure the congruency of organizational goals with actual achievement, instructor training, course development, instructor-learning interactions, student support, assessment, and paths of student success upon graduation (Wright, 2007c). Also of concern is the lack of meaningful interaction that promotes higher-order or critical thinking. Quality affects student achievement, graduation rates, the potential for students to obtain a job or to pursue further education upon graduation, the support of educational stakeholders, and the image or creditability the institution has within the community.

Various countries need accreditation agencies to develop and customize quality criteria for assessing distance education; they should not simply use those for traditional institutions, some of which do not address the peculiarities of distance learning systems. In some cases, staff who migrate from traditional systems to open and distance learning (ODL) institutions bring with them protectionist policies that may not help the ODL institutions to achieve their overall goals, especially goals related to accessibility, flexibility, and equity. Staff in new ODL institutions in emerging nations must be introduced to attributes of ODL that differentiate it from classroom teaching.

Quality assurance systems should have a higher priority when resources are limited, but they often receive little or no funding. Distance educators do not need to develop their own standards from scratch; they can obtain existing standards and modify them for their environment. In any event, they should publicize the standards they are using and ask external examiners to review their progress in achieving these standards.

\section{Recognizing those who are Likely to Succeed and Addressing Student Needs}

Educational opportunities should be available to everyone. People who live on the street and in rural areas, as well as those in affluent communities, have a right to an education. However, when new programs and institutions are established, government and funding agencies usually focus on completion or graduation rates in determining whether funding should be continued and programs expanded. Since distance education programs may suffer from low completion rates (Perraton, 2007), it might be advantageous for project initiators to consider who will likely be successful with distance education courses and initially offer programs that will meet the needs of these types of students. The results should yield high completion rates thus attracting further funding that can be used to develop programs for higher-risk students.

Successful online or e-learning students are likely to be highly-motivated, well-organized, selfdisciplined, good time managers, supported by family and colleagues, able to tolerate ambiguity, flexible, goal-oriented, and interested in using technology (Wright, 2008a). Post-secondary level students are likely to be more successful with distance education than primary students (Perraton, 2007). This does not mean that only these types of students will succeed, but rather that they are more likely to complete a certificate, diploma, or degree program. 
Adult learners are particularly motivated if at the end of their studies they will obtain an accreditation, a salary increase, and/or a promotion that will enable them to leave poverty behind and improve the lives of their families. Distance education seems to be ideally suited for those who have full-time jobs and family responsibilities, are disabled or house-bound, are geographically dispersed, or are far away from home, for example, military personnel, embassy staff, missionaries, international volunteers, and refugee workers. These individuals recognize the need for access to education that is not bound by time and place. Distance education is also of interest to those who want life-long learning courses. If developing countries want to maximize their investment in distance education, they should take into account those students who are likely to make the best use of this form of educational delivery system and provide effective student support.

Students may need access to financial support, equipment and technological support, learning resources, and academic advisers. A number of these student services may be provided in a virtual form (Brigham, 2001). In many cases, costs borne by the typical traditional institution, such as printing, are passed on to students who can ill afford an additional financial burden. In collaboration with the Canadian International Development and Research Centre (see http://www.idrc.ca), countries such as Benin, Egypt, Kenya, South Africa, and Uganda have established a network of telecentres to provide affordable access to information and to support students as well as to promote the use of ICTs for community development.

In addition to issues related to the cost of equipment, access to the Internet, lack of familiarity with technological tools, limited access to up-to-date and engaging resources, and the need for quality assurance systems that lead to accreditation and increased job prospects, students have other concerns that must be addressed. These concerns may contribute to attrition rates that can be $10 \%$ to $20 \%$ higher for distance education than for traditional face-to-face instruction (Angelino, Williams, \& Natvig, 2007). Humans tend to be social beings who rely heavily on eyecontact, verbal cues, immediate feedback, and frequent contact with others. If these social factors are not addressed, distance education may lead to the feeling of isolation (Hellman, 2003). Students may feel the need to be part of a community - a community of learners. If educational technologies available to them do not provide opportunities for interaction then tutors, study groups, and the involvement of family and peers should be built into the program so learners do not feel isolated. It may be necessary to inform employers and family members about the longterm benefits of the education being sought and encourage them to support the learner. Students may want frequent contact with their instructor or tutor in order to obtain feedback that is timely, effective, and nurturing. The number of potential challenges facing students in developing countries is significant, but they can be overcome if careful attention is given to addressing their needs.

\section{Dealing with Faculty Concerns}

Faculty may not support a learning system that is substantially different from the traditional, postcolonial, face-to-face instructional environment in which they were trained. The implementation of distance education may be impeded by faculty who have limited or no experience with 
distance education (Gulati, 2008). Their students may also need to be weaned from a face-to-face learning environment. If institutions value research and publications rather than the time and effort required to produce and support distance education courses, faculty may not have the support they need to make the transition to an electronic form of distance education (Anderson \& Middleton, 2002; Levitch \& Milheim, 2003). They may develop teaching anxiety associated with (a) the lack of training with the new technology and instructional methods, (b) the tension between allocating time to online course development and research, (c) increased workload, and (d) performance expectations in an unfamiliar learning and instructional environment in which learner-centred and constructivist approaches may be emphasized. These faculty concerns are evident in developing countries such as Botswana (Wright, 2007c) as well as in more economically advanced countries such as Brazil (Porto \& Berge, 2008).

Technical support is often lacking in developing countries, as the few individuals with technical expertise focus on network infrastructure and security. Faculty must learn how to install and maintain computers and software and troubleshoot problems that they and their students encounter (Wright, 2007b). Instructors also need to learn a variety of online competencies (Smith, 2005), especially how to foster active learning (Moore, Fowler, \& Watson, 2007), build effective interaction into their courses (Flottemesch, 2000), manage their time (Ally, 2000; Shi, Bonk \& Magjuka, 2006), and write effectively (Thomas, 2007). Often overlooked is the need to inform instructors and students about copyright and electronic plagiarism as well as to encourage them to question what they locate on the web and to verify web content. Governments and institutions should be encouraged to establish laws and policies that support the free exchange of information for educational purposes.

One of the major challenges faced by faculty as they try to learn about technology is that they do not have easy access to it. Since 2006, the National Open University of Nigeria has provided laptops with general packet radio service (GPRS) and Internet-enabled wireless cards to ease communication among its staff, especially the study centre staff and instructors on the main campus. The computers are provided via a very flexible loan arrangement between the staff and the university management. Each Internet card has a monthly airtime credit of US\$39. Some institutions purchase large quantities of computers at reduced rates and provide their distance education instructors with the technology.

Students are a resource that is often overlooked when faculty training is being implemented. In general, young people tend to pick up technology skills rapidly and can be used to assist instructors in learning computer skills and developing media-based materials (Wright, 2007b). If this is to occur, faculty may need to overcome their resistance to learning from students, which may be accomplished more easily in some cultures than in others.

To provide faculty with current information and skills pertaining to distance learning, institutions and governments in countries such as Bangladesh, Ghana, Nigeria, and Sri Lanka invite consultants from international development agencies that are usually based in Australia, Canada, England, Germany, the Netherlands, Sweden, and the United States. If the consultants are not careful, they bring with them their unfiltered Western views and provide one-way "information 
dumps" that do not offer opportunities for participants to discuss how to adapt what they have heard. For example, the tutoring models in the West usually involve one instructor with a few students; however, this would be unsustainable in developing countries (Lentell \& O'Rourke, 2004). Developing country hosts should insist that the training sessions be interactive and allow time for reflection and the development of local solutions. Educators should be encouraged to obtain diverse views from reliable Web sites and blogs such as EDUCAUSE (see http://www.educause.edu/), Stephen's Web (see http://www.downes.ca/), and ZaidLearn (see http://zaidlearn.blogspot.com/). Educators should actively participate in organizations, such as the MERLOT Africa Network (MAN, see http://man.merlot.org/), that focus on the scholarship of teaching and learning using electronic resources,

\section{Accessing Up-to-Date Educational Resources}

Open educational resources and digitized print resources can help alleviate situations arising from the paucity of up-to-date educational resources. Sources of open courseware include the OpenCourseWare Consortium (see http://ocwconsortium.org/), which provides access to university courses from Australia, China, Colombia, France, Japan, Korea, Mexico, the Netherlands, Spain, Taiwan, the United Kingdom, the United States, and Vietnam. The Open Educational Resources Commons (see http://www.oercommons.org/) offers teaching and learning material at the basic, secondary, and college levels. Items can be retrieved online and transferred to compact discs or memory/USB keys for use in areas where Internet accessibility and bandwidth are limited. In 2008 the South African Institute for Distance Education (SAIDE) established Open Educational Resources (OER) Africa (see http://www.oerafrica.org/) to harness the benefits of OER for higher education systems in Africa. The Opencast Community (see http://www.opencastproject.org/) is a collaboration of higher education institutions that provides audio and video captures of lectures at leading universities.

Most importantly, educators in developing countries need to overcome the "not-invented-here syndrome" by re-branding, localizing, or contextualizing material they obtain from other sources (Wright, 2007a). If a course developed by another institution is not available in an open-source format, they must obtain permission to use it and then simply re-brand it by adding their institution's name, logo, and contact information. The materials are not changed significantly and considerable time is saved. Educators may decide to localize material by removing inappropriate information, including local examples, or rearranging course components. The OpenLearn LabSpace (see http://labspace.open.ac.uk/), managed by the British Open University, enables users to download and remix course content. Distance educators may also contextualize the material for a local audience by changing its content and syntax. The African Virtual University (AVU, see http://www.avu.org/) aims to provide world-class quality education and training programs to educators in Africa as well as undergraduate and remedial academic courses. One of the major challenges is to adapt course materials developed in an affluent Western context to the educational environment in Africa. According to Lou Siragusa of Curtin University of Technology in Australia, material that has been adapted successfully must balance Australian, international, and African perspectives. It must allow students to reflect on the knowledge in their 
own countries, yet enable them to draw on expertise and experience from other countries (Wright, 2007d).

The eGranary Digital Library (see http://www.egranary.org) or "The Internet in a Box" initiative managed by the University of Iowa enables people in developing countries to access recent information without incurring Internet charges or struggling with limited bandwidth (Jeffrey, 2007). The library comprises more than 10 million Web pages including Massachusetts Institute of Technology (MIT) OpenCourseWare (see http://ocw.mit.edu/), Project Gutenberg's (see http://www.gutenberg.org) classic literature collection, 40,000 books, and 200 full-text journals. The material is stored on Windows or Linux servers costing as little as US $\$ 2,800$ that plug into existing local networks. These servers provide access to information that can be up to 5,000 times faster than the satellite links that are used primarily in Africa and the South Pacific. They are currently located in institutions in Africa, Bangladesh, Haiti, and India. Institutions are charged an annual fee of US\$200 for twice yearly updates. A search engine is provided that allows users to search all content, including content they add themselves. The eGranary Digital Library, MIT's OpenCourseWare, and other similar open source initiatives have enabled learners such as Olumide in Nigeria to state, "As a student in a developing African country, OCW is helping me access knowledge and information I never dreamed of getting. It's inspiring me to push harder and enjoy learning with the assurance that I'm getting the best' (d'Oliveira, 2008).

\section{Implementing Mobile Learning}

Although implementing mobile learning is not a recurring issue as educators have not previously encountered this method of delivery, it is an emerging issue for developing countries. As they are trying to implement online learning effectively, developing countries are also exploring the use of mobile technology. As we all know, the small screen and the current inputting devices make them difficult to use for many educational purposes; however, the devices are more affordable than computers, are socially acceptable in all strata of society, are easy to use, and are everywhere. In Africa mobile phones are used to contact groups of educators such as teachers and principals with specific messages related to administration and educational content. Mobile phones are also used to transmit attendance or submit grades, to contact students about class activities or cancellations, and to record and distribute photographs and audio or podcast recordings. In Nigeria, mobile phones are used to teach literacy to some of the 9.3 million nomads who wander over its terrain or along its shoreline (Aderinoye, Ojokheta, \& Olojede, 2007). The phones are also used to send job listings and health information to low-income residents of Cameroon and Uganda and to enable doctors to diagnose patients in remote areas in Kenya and Tanzania (Developments.org, 2007; TRALAC, 2008). Ericsson will establish an innovation centre in sub-Saharan Africa to develop mobile applications in health, education, agriculture, and small business that will focus on "meeting the needs of poor and rural populations...in Ericsson's ongoing commitment to support the achievement of the UN's Millennium Development Goals" (iConnect Online, 2008). The projects described in this paragraph do not currently have the individualized learning aspects that most would consider to be an important ingredient of quality distance education programs, but they are a step in the right direction; they are providing educational resources and opportunities to those who have had limited or no access. 
A London Business School study indicated that an increase of ten mobile phones per hundred people boosts the economical growth rate of developing countries by $0.6 \%$ ("Economics Focus," 2005). There is no doubt that with the tremendous growth of mobile phones in developing nations, the interest educators express in using these devices, and the involvement of mobile phone manufacturers in projects that will expand educational opportunities, a time will come when the phones are used not just for communicating, conducting financial affairs, and performing administrative tasks, but also for in-depth learning and assessment. The future of mobile learning is unwritten, but it may become the foundation of an exponential growth in distance learning because mobile appliances are ubiquitous, affordable, and have wireless capabilities that can reach urban and rural areas that lack a terrestrial infrastructure. However, those who adopt mobile learning are likely to encounter the issues discussed above relative to online learning.

\section{Conclusion}

Despite the challenges described in this article, new institutions are launched each year, existing traditional institutions are expanding their open learning options, and enrolment in distance education courses continues in both the developed and developing worlds. The continued growth and success of distance education institutions will depend on the extent to which issues covered in this article are addressed, as they all affect the quality of the learning experience provided to students. For those in developing and emerging nations, distance education is the promise of a better life, not just an enhancement of existing educational offerings. 


\section{References}

Aderinoye, R. A., Ojokheta, K.O., \& Olojede, A. A. (2007, June). Integrating mobile learning into nomadic education programmes in Nigeria: Issues and perspectives. International Review of Research in Open and Distance Learning, 8(2). Retrieved July 8, 2008, from http://www.irrodl.org/index.php/irrodl/article/view/347/919

Ally, M. (2000). Tutoring skills for distance education. Open Praxis, 1, 3134.

Anderson, S. K., \& Middleton, V., (2002). You want me to do what? The cultural and psychological struggle of putting a course online. The Technology Source. Retrieved July 10, 2008, from http://technologysource.org/article/you_want_me_to_do_what/

Angelino, L. M., Williams, F. K., \& Natvig, D. (2007, July). Strategies to engage online students and reduce attrition rates. The Journal of Educators Online, 4(2). Retrieved July 8, 2008, from http://www.thejeo.com/Volume4Number2/Angelino\%20Final.pdf

Association for Progressive Communications (APC) (2008, October 13). Why APC continues to obsess over Internet access. Retrieved October 15, 2008, from http://www.apc.org/en/news/development/all/why-apc-continues-obsess-over-internetaccess

Balancing Act News Update (2008, October 5). Liberia's Minister highlights plan for ICT. Retrieved October 6, 2008, from http://www.balancingactafrica.com/news/current1.html\#computing

Bates, A. W. (2000). Managing technological change: Strategies for college and university leaders. San Francisco, CA: Jossey-Bass.

BBC News (September 9, 2008). Africans to gain from web plan. Received September 12, 2008, from http://news.bbc.co.uk/2/hi/africa/7606824.stm

Brigham, D. (2001). Converting student services to online services. International Review of Research in Open and Distance Learning, 1(2). Retrieved July 7, 2008, from http://www.irrodl.org/index.php/irrodl/article/view/23/59

Bunn, M. D. (2001). Timely and timeless issues in distance education planning. The American Journal of Distance Education, 15(1), 5568.

Butcher, N., \& West, P. (2007). The virtual university for the small states of the Commonwealth. In Commonwealth Secretariat, Nexus Strategic Partnerships \& Commonwealth Secretariat Staff, Commonwealth education partnerships 2007 (pp. 102106). London: Nexus Strategic Partnerships. 
Chibomba, K. (2007, August 8). Africa's ICT development still "haunted" by the past. OneWorld Africa. Retrieved August 11, 2007, from http://africa.oneworld.net:80/article/view/152062/1/

Coppola, C. D. (2004). Will open source unlock the potential of e-learning? Campus Technology. Retrieved June 22, 2008, from http://campustechnology.com/articles/40044/

Developments.org (2007). Mobile phones help fight poverty in Africa. Retrieved August 8, 2007, from http://www.developments.org.uk/articles/mobile-phones-help-fight-poverty-inafrica/

Dhanarajan, G. (2001). Distance education: Promise, performance and potential, Open Learning, $16(1), 6168$.

d'Oliveira, C. (2008, October 7). Invest in open. MIT OpenCourseWare Update. Boston, MA.: MIT OpenCourseWare.

Economics focus: Calling across the divide. (2005, March 12). The Economist. Retrieved June 12, 2008, from http://www.london.edu/assets/documents/PDF/The_EconomistCallingAcrossThe_Divide.pdf

Edmundson, A. (Ed.). (2007). Globalized e-learning cultural challenges. Hershey, Pennsylvania: Information Science Publishing.

Fay, M., \& Morrison, M. (2007) Infrastructure in Latin America and the Caribbean: Recent developments and key challenges. Washington, DC: World Bank Publications.

Fernández-Maldonado, A. M. (2004, June 8). Commerial cybercafes: A useful weapon against the "Digital Divide"? Retrieved September 12, 2008, from http://www.elearningeuropa.info/directory/index.php?page $=$ doc $\&$ doc $\mathrm{id}=5077 \& \mathrm{doclng}=$ $\underline{6}$

Flottemesch, K. (2000, May/June). Building effective interaction in distance education: A review of the literature. Educational Technology, 4651.

Gordon, R. G., Jr. (Ed). (2005). Ethnologue: Languages of the world (15th ed.). Dallas, Texas: SIL International.

Gross. D. A. (2006, February 7). New technologies and the rise of political liberty. Remarks made at the 2006 Grafstein Lecture in Communications, Faculty of Law, University of Toronto, Canada. Retrieved June 22, 2008, from http://www.state.gov/e/eeb/rls/rm/2006/61085 
Gulati, S. (2008, February). Technology-enhanced learning in developing nations: A review. International Review of Research in Open and Distance Learning, 9(1). Retrieved July 10, 2008, from http://www.irrodl.org/index.php/irrodl/article/view/477/1011

Hellman, J. A. (2003). The riddle of distance education: Promise, problems and applications for development. Geneva, Switzerland: United Nations Research Institute for Social Development.

iConnect Online (2008, September 30). Ericsson to launch mobile Innovation Center in Africa. Retrieved, October 2, 2008), from http://www.iconnect-online.org/News/ericsson-tolaunch-mobile-innovation-center-in-africa

Jeffrey, T. (2007, July 17). Africa: "Internet in a Box" brings information to developing world. $\begin{array}{lllll}\text { allAfrica.com. } & \text { Retrieved July } & \text { 2008, from }\end{array}$ http://allafrica.com/stories/200707181318.html

Leary, J., \& Berge, Z. L. (2006). Trends and challenges of e-learning in national and international agricultural development. International Journal of Education and Development Using ICT, 2(2). Retrieved July 10, 2008, from http://ijedict.dec.uwi.edu/viewissue.php?id=8

Leggett, W. P., \& Persichitte, K. A. (1998, April/May) Blood, sweat, and tears: 50 years of technology implementation obstacles, 5(1). TechTrends, 3336.

Lentell, H., \& O’Rourke, J. (2004, April). Tutoring large numbers: An unmet challenge. International Review of Research in Open and Distance Learning. 5(1). Retrieved June 14, 2008, from http://www.irrodl.org/index.php/irrodl/article/viewFile/171/685

Levitch, S., \& Milheim, W. D. ( 2003, MarchApril). Transitioning instructor skills to the virtual classroom. Educational Technology, 4246.

Levy, S. (2003, Spring). Six factors to consider when planning online distance learning programs in higher education. Online Journal of Distance Learning Administration, 6(1). Retrieved July 11, 2008, from http://www.westga.edu/ distance/ojdla/spring61/levy61.htm

Lindow, M. (2008, October 24). Virtual network planned to connect American and African universities. The Wired Campus. Retrieved October 26, 2008, from: http://chronicle.com/wiredcampus/article/3414/virtual-network-planned-to-connectamerican-and-african-universities

Mahan, A. (2007). Conclusion: ICT and pro-poor strategies and research. In Digital poverty: Latin American and Caribbean Perspectives (pp. 141156). Ottawa, Canada: International Development Research Centre.

Mandela, N., \& Machel, G. (2002, May 1). We must teach all the children. The Globe and Mail, 
A15.

McDonald, J. (2007, August 3). Lenovo targets China's rural poor with \$199 PC. E-Commerce $\begin{array}{llll}\text { Times. } & \text { Retrieved July } & \text { 2008, from }\end{array}$ http://www.ecommercetimes.com/rsstory/58657.html

Ministry of Education, Science, \& Technology, Government of Kenya (2005). ICT in education options paper. Washington, DC: USAID. Retrieved June 19, 2008, from http://pdf.usaid.gov/pdf_docs/PNADI898.pdf

Moore, A. H., Fowler, S. B., \& Watson, C. E. (2007, September/October). Active learning and technology: Designing change for faculty, students, and institutions. EDUCAUSE Review, 42(5), 4261.

Muilenburg, L., \& Berge, Z. L. (2001). Barriers to distance education: A factor-analytic study. The American Journal of Distance Education, 15(2), 722. Retrieved June 29, 2008, from http://www.emoderators.com/zberge/fa ajde 050401.shtml

Nafukho, F. (2007, March). The place of e-learning in Africa's institutions of higher learning. Higher Education Policy, 20(1), 1943.

Narayan, G. (2007). Address the digital divide: E-governance and m-governance in a hub and spoke model. The Electronic Journal of Information Systems in Developing Countries, 31(1), 1-14. Retrieved June 22, 2008, from http://www.ejisdc.org/ojs2/index.php/ejisdc/article/view/312

Ng, S. (2007, August 5). Education for everyone. The Star. Retrieved August 8, 2007, from http://thestar.com.my:80/education/story.asp? file=/2007/8/5/education/18096310

Ngare, P. (2007, June 8). Kenya: Country takes steps to adopt e-learning. allAfrica.com. Retrieved August 7, 2007, from http://allafrica.com/stories/200706080176.html

Nixon, R. (2007, July 21). Africa, offline: Waiting for the web. International Herald Tribune. $\begin{array}{llll}\text { Retrieved June 24, 2008, from } & \text { 24 }\end{array}$ http://www.iht.com/articles/2007/07/22/africa/22rwanda.php

Okono, F. (2007, August). Refurbished computers: The complete package. ICT Update, 38. Retrieved June 22, 2008, from http://ictupdate.cta.int/en/feature articles/the complete package

Omofaye, J. O. (2006, September). Challenges facing ICT infrastructure and successful online education in Africa. Paper presented at the 22nd International Council for Open and Distance Education (ICDE) World Conference on Distance Education, Rio de Janeiro, Brazil. 
Perraton, H. (2007). Open and distance learning in the developing world (2nd ed.). London: Routledge.

Porto, S. C. S. \& Berge, Z. L. (2008, June). Distance education and corporate training in Brazil: Regulations and interrelationships. International Review of Research in Open and Distance Learning, 9(2). Retrieved July 7, 2008, from http://www.irrodl.org/index.php/irrodl/article/view/478/1052

Rennie, F., \& Mason, R. (2007, March). The development of distributed learning techniques in Bhutan and Nepal. International Review of Research in Open and Distance Learning, 8(1). Retrieved, June 20, 2008, from http://www.irrodl.org/index.php/irrodl/article/viewFile/339/775

Shi, M., Bonk, C. J., \& Magjuka, R. J. (2006, February). Time management strategies for online teaching. International Journal of Instructional Technology and Distance Learning. Retrieved July 10, 2008, from http://itdl.org/Journal/Feb 06/article01.htm

Sife, A. S., Lwoga, E. T., \& Sanga, C. (2007). New technologies for teaching and learning: Challenges for higher learning institutions in developing countries. International Journal of Education and Development Using ICT, 3(2). Retrieved July 8, 2008, from http://ijedict.dec.uwi.edu/viewarticle.php?id=246

Silberstein, N. (2007). Public universities leading the way in online learning. News Channel 5.com, Nashville, Tennessee, USA. Retrieved September 21, 2007, from http://www.newschannel5.com/Global/story.asp?S=7024727. Available at http://www.umassonline.net/news/1116.html

Smith, T. C. (2005, July). Fifty-one competencies for online instruction. The Journal of Educators Online, 2(2). Retrieved June 28, 2008, from http://www.thejeo.com/Ted\%20Smith\%20Final.pdf

Strong, B. (2007). Strategic planning for technological change. EDUCAUSE Quarterly, 30(3). Retrieved June 12, 2008, from http://www.educause.edu/apps/eq/eqm07/eqm0737.asp

Thomas, R. (2007, August 8). Online training for online faculty: A checklist of the best strategies for designing and delivering online courses to train online faculty. Campus Technology. $\begin{array}{llll}\text { Retrieved June 22, 2008, from } & \end{array}$ http://www.campustechnology.com/article.aspx?aid=49570

Thornton, L. (2008, September 25). Why African governments need to listen to the case for "open access" to international communications infrastructure. Association for Progressive Communications News. Retrieved September 29, 2008, from 
http://www.apc.org/en/news/openaccess/africa/why-african-governments-need-listencase-open-acce

TRALAC (Trade Law Centre for Southern Africa, 2008, October 9). New technology sweeps African continent. TRALAC Newsletter. Retrieved October 10, 2008, from http://www.tralac.org/cgibin/giga.cgi?cmd=cause dir news item\&news id=54127\&caus e_id=1694

Trindade, A. R., Carmo, H., \& Bidarra, J. (2000). Current developments and best practice in open and distance learning. International Review of Research in Open and Distance Learning, 1(1). Retrieved July 9, 2008, from http://www.irrodl.org/index.php/irrodl/article/view/7/20

Wadvalla, B. (2008, August 1). Africa still dependent on satellite net access. Science and Development Net. Retrieved August 7, 2008, from http://www.scidev.net/en/news/africastill-dependent-on-satellite-net-access.html

Wagner, D. A., Day, B., James, T., Kozma, R. B., Miller, J., \& Unwin, T. (2005). Monitoring and evaluation of ICT in education projects: A handbook for developing countries. Washington, DC: Information for Development Program (InfoDev) and the World Bank.

Wallsten, S. (2005). Regulation and internet use in developing countries. Economic Development and Cultural Change, 53, 501-523.

Wells, R., \& Wells, S. (2007). Challenges and opportunities in ICT educational development: A Ugandan case study. International Journal of Education and Development Using ICT, 3(2). Retrieved June 28, 2008, from http://ijedict.dec.uwi.edu/viewarticle.php?id=296\&layout=html

Wheeler, B. (2004). Open source 2007: How did this happen? EDUCAUSE Review, July/August, 12-27. Retrieved June 12, 2008, from http://www.educause.edu/er/erm04/erm0440.asp

World Bank (2007a, April 2). Africa Regional Communications Infrastructure Program (RCIP). Global Information and Communication Technologies of the World Bank. Retrieved August 12, 2007, from http://web.worldbank.org/WBSITE/EXTERNAL/TOPICS/EXTINFORMATIONANDC OMMUNICATIONANDTECHNOLOGIES/0, contentMDK:20940326 pagePK:210058 $\sim$ piPK:210062 theSitePK:282823,00.html

World Bank (2007b, August 29). Inclusive growth consultations. Retrieved July 13, 2008, from http://www.worldbank.org.in/WBSITE/EXTERNAL/COUNTRIES/SOUTHASIAEXT/I NDIAEXTN/0,,contentMDK:21483221 pagePK:141137 piPK:141127 theSitePK:2955 $\underline{84,00 . h t m l}$ 
Wright, C. R. (2006, November). Selecting an open-source online course development and delivery platform: An academic perspective. Paper presented at the Fourth PanCommonwealth Forum on Open Learning: Achieving Development Goals, Ocho Rios, Jamaica. http://pcf4.dec.uwi.edu/index.php

Wright, C. R. (2007a, May). Adapting educational materials for elearning. Paper presented at eLearning Africa Conference, Nairobi, Kenya. http://www.elearning-africa.com/

Wright, C. R. (2007b). Charting the way forward. Unpublished manuscript, GIATMARA Vocational Institutes, Kuala Lumpur, Malaysia.

Wright, C. R. (2007c, December 5). Implementing technology in emerging nations. Presentation to the National e-Learning Steering Committee of Botswana. Meeting held at the University of Botswana, Gaborone, Botswana.

Wright, C. R. (2007d). Knowledge series: Adapting learning materials for distance learning. Vancouver, Canada: Commonwealth of Learning. Retrieved June 12, 2008, from http://www.col.org/colweb/site/pid/3129

Wright, C. R. (2008a, March 19). Beyond our North American borders. Online presentation for the Canadian Network for Innovation in Education (CNIE).

Wright, C. R. (2008b, June 20). Dimensions of quality: Reflections on Current Practice. Keynote address at the Canadian e-Learning Conference, Calgary, Alberta, Canada.

Zeleza, P. T. (2005). Postscript: Challenges of the ICT revolution in East Africa. In F. E. Etta \& L. Elder (Eds.), At the crossroads: ICT policy making in East Africa (pp. 283-294). Nairobi, Kenya: East African Educational Publishers and Ottawa, Canada: International Development Research Centre.

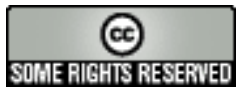

